\title{
Europe in Sweden
}

\author{
Christina Segerholm and Agneta Hult
}

\begin{abstract}
The increased importance given to European policy concerning evaluation and quality assurance in higher education in the Swedish national policy context is explored in this chapter. The description rests on interviews with what here is labelled policy brokers and on the material from the European Association for Quality Assurance in Higher Education (ENQA), as well as government bills, parliamentary minutes, national agency reports, and university teachers' union journals. The results show that ENQA membership requirements played a significant role in the Swedish policy debate on the design of the 2016 national evaluation and quality assurance system. Dissemination channels between Europe and Sweden are populated by individuals with similar functions and positions, e.g. that ministers often meet ministers. Within Sweden, European policy is disseminated by and through individuals who move between different positions within the ministry of education, national agencies, and higher education institutions. Different organisations also communicate with each other within Sweden, ensuring European policies reaching into higher education institutions. Such European governing attempts are carried out in activities like networks, conferences, papers, guidelines, and by using different forms of knowledge, both inscribed, embodied, and enacted.
\end{abstract}

\section{Introduction}

In the previous chapter, we analysed the development of national evaluation and quality assurance systems mainly as a national issue. However, we also noted that Sweden's engagement in the Bologna Process influenced the evaluation and quality assurance systems, for example, by placing an increased stress on expected learning outcomes. The European policy agenda also gained power in the debate following the membership status of the Swedish National Agency for Higher Education (SNAHE) in the European Association for Quality Assurance in Higher Education

C. Segerholm $(\bowtie) \cdot$ A. Hult

Department of Education, Umeå University, Umeå, Sweden

e-mail: christina.segerholm@umu.se; agneta.hult@umu.se

(C) The Author(s) 2019

C. Segerholm et al. (eds.), The Governing-Evaluation-Knowledge Nexus,

Evaluating Education: Normative Systems and Institutional Practices,

https://doi.org/10.1007/978-3-030-21143-1_3 
(ENQA) following the 2011-2014 national system. The amplified importance of European evaluation and quality assurance policy for Sweden is portrayed in this chapter. We will deepen the study of European influence and governing potential and explore the European arena and its relation to Swedish higher education policy concerning evaluation and quality assurance (EQA). ${ }^{1}$

Knowledge and ideas about evaluation and quality assurance may exist in national/state agencies to a lesser or larger degree. As shown in the previous chapter, Sweden has used a handful of national evaluation and quality assurance systems for higher education during the last decades, and, through these processes, certain knowledge about EQA and governing has been acquired (e.g. Franke and Nitzler 2008; Kettis and Lindberg-Sand 2013). Such knowledge has progressively been brought together and circulated in transnational spaces (e.g. the ENQA 2010). Through these transnational spaces, circulation or dissemination of policies and knowledge about EQA among national/state agencies and contexts also takes place.

Since the signing of the Bologna agreement for European higher education, a number of initiatives, programmes, and organisations have been launched. These efforts can be summarised by the concept of "Europeanisation" (e.g. Grek and Lawn 2012; Jacobsson 2010a). An explicit political purpose is to safeguard Europe's position on the global market. Education is believed to promote this, and it is argued that student, teacher, and researcher mobility would facilitate this ambition (Standards and Guidelines for Quality Assurance in the European Higher Education Area, ESG, 2015, p. 6). Coordination of different national education systems is one way to sustain this mobility ambition. As higher education is not regulated by European laws and regulations, processes of coordination must rely on "soft" governing (Lawn 2006) through means like the open method of coordination, which is based on:

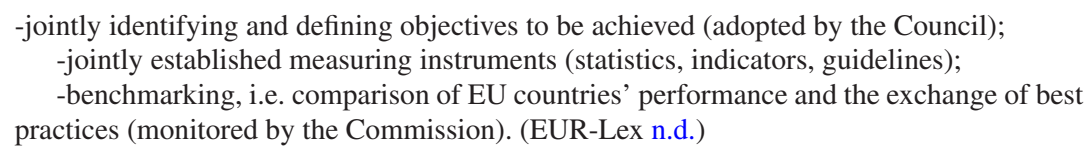

It is also said that to support and increase mobility, national higher education systems have to be trusted to deliver high-quality education, and it is claimed that quality assurance (QA) is the means to achieve this (ESG 2015, p. 6). In the last decades, a number of reforms have been implemented, and multiple QA activities have been performed (Maassen and Stensaker 2011).

One of these initiatives and from 1999 specifically directed at ensuring "more comparable, compatible and coherent systems of higher education in Europe" is the European Higher Education Area, (EHEA n.d.-a). A central purpose of the Bologna Process, and hence the EHEA, is to "encourage European cooperation in quality assurance of higher education with a view to developing comparable criteria and methodologies" (EHEA n.d.-b). For this reason, the European ministers of education

\footnotetext{
${ }^{1}$ The chapter is based on two conference papers that have been revised and updated: Segerholm and Hult $(2015,2017)$.
} 
agreed to support the Standards and Guidelines for Quality Assurance in the Higher Education Area (ESG) in 2005, which was drafted by the European Association for Quality Assurance in Higher Education, ENQA (ENQA 2009; Thune 2010), and revised in 2015 (Standards and Guidelines for Quality Assurance in the European Higher Education Area (ESG) 2015).

In spring 2019, 50 QA agencies in 28 countries were full members of the ENQA, which means that they met QA policies and practices set up by the organisation. Since all EQA activities are part of governing work (Ozga et al. 2010), our argument is that ENQA membership (or striving for ENQA membership) can be significant when attempting to understand how certain governing policies and practices are brokered and translated into the European context and beyond.

In this chapter, we investigate the significance of membership in the ENQA and its relation to the governing of higher education. Here, Sweden is an interesting example in that its national agency for higher education was a full member of the ENQA, but this status was questioned in 2012 (ENQA 2012), and membership was revoked in February 2014 (ENQA 2014a). This state of affairs fuelled an already existing debate about the shortcomings of the national EQA system in existence from 2011 to 2014 and was linked to political discussions about the design of a new EQA system, which we analyse more thoroughly in the chapter "Hayek and the Red Tape: The Politics of Evaluation and Quality Assurance Reform - From Shortcut Governing to Policy Rerouting". The specific focus of this chapter is the relation between the ENQA's policy and Sweden's policies on EQA and the channels by which European policy enters Sweden. We recognise that policy dissemination and circulation (i.e. brokering) may occur in bi- or multidirectional processes, not just from one part or level to another. The special situation of the Swedish agency's nonENQA membership did however produce a particular national policy context in which European and ENQA policy became very influential. Our aim is, therefore, to explore the influence of the ENQA policy on the Swedish national EQA policy in higher education and how the ENQA policy enters the Swedish policy context and forms part of the governing of Swedish higher education during a period of nonmembership of the Swedish agency.

The questions we pursue are:

- How is the ENQA's policy visible in the Swedish national policy process?

- Through what channels was ENQA policy disseminated, and what policy was perceived as important in Swedish national policymaking?

- How does ENQA policy relate to the governing of higher education in Sweden?

\section{Theoretical Notes, Methods, and Material}

In this book, we have emphasised governing as a verb, i.e. to focus on activities and the work that is "done", be it by talking to people, writing texts, arranging and participating in meetings and workshops, and/or by decision-making bodies. In this 
context and as we outlined in the chapter "Governing by Evaluation: Setting the Scene", we conceptualise "governing" as a verb so as to underline that attempts to develop, disseminate, and implement policy require activities and work, as do attempts to develop and disseminate practice.

In an effort to promote stronger and more unified education policies throughout Europe, different activities are carried out to influence member countries (and perhaps others) to accept and also develop similar policies and practices. As we will show in this chapter, different methods are used to increase the governing power of European policies. Ways of disseminating policy and practice that can influence (govern) beyond the central European sphere have been described and analysed by Jacobsson (2010a, b) through the concepts of "regulative, inquisitive, and meditative" governing activities. "Regulative" refers to activities like rule-making and mandatory obligations where penalties can be invoked if the rules are broken. "Inquisitive" activities require organisations to be open to examination, inquiry, scrutiny, and/or different sorts of assessments. Finally, "meditative" activities, which form the foundation of the other two, are in themselves a separate type of activity that includes verbal and written interaction, sometimes in spaces particularly aimed for such activities (e.g. workshops, meetings, conferences) where the exchange of experiences and probing of common issues are central (Jacobsson 2010a, pp. 4-6.) This conceptual frame also points to different ways that policy may be brokered and disseminated.

The importance of national and local contexts in these processes (Ozga and Jones 2006; Steiner-Khamsi 2004; Sassen 2007) is also noted. European education policy has to make national sense and be translated and interpreted to fit specific national contexts so as to influence already existing policy and practice. In European governing and policy work, nation-states are more or less actively involved. Involvement requires balancing internal national interests with national and international requirements. To come to international agreements and consensus on ENQA membership requirements, active work is needed by nation-states, sometimes with actors holding oppositional views (see Sassen 2007) where struggles and conflicts occur over time and have to be addressed. Therefore, national and local contexts affect when, how, and what policies travel, how they are disseminated and translated, and how governing influenced by international (European) policies is possible. In the Swedish case, several actors take part in discussing higher education policy and the EQA system(s), and the state (government and agencies) has interacted with these actors in different ways during the periods we studied (see also the chapter "Hayek and the Red Tape: The Politics of Evaluation and Quality Assurance Reform - From Shortcut Governing to Policy Rerouting"; Lindgren and Rönnberg 2015). There are also actors that function as links, or brokers, between Sweden and the European/global space. These are what Lawn and Lingard (2002) call "policy elites", composed of actors like ministers, high-ranking civil servants, and experts in different policy fields. They meet in different organisations to discuss mutual policy issues, exchange experiences, and decide on common policies and actions.

This chapter is based on interviews with ten such national policy brokers carried out mainly in spring 2015. We also collected and analysed a variety of documents 
from the ENQA and other European organisations, from Swedish government bills and parliamentary minutes, documents, etc., and documents from the two national agencies responsible for supervising higher education in Sweden. In addition, we also analysed material from the university teacher union's journal and daily national press (Svenska Dagbladet).

Next, a description of the ENQA is presented based on official ENQA documents. We then scrutinise the ENQA influence through its membership requirements and relate them to the Swedish EQA contexts, showing that European governing attempts through QA policies enter the national context of Swedish QA. In this account, we also insert examples of the internal national debate in Sweden to exemplify the influence of the ENQA on the national policy space. Next, we investigate how these Europeanising processes are experienced and handled by what we here call national policy brokers and through which channels European policies enter Sweden. We then describe these intranational dissemination channels. The chapter ends with a discussion of our findings, which we discuss in relation to the importance of governing by comparison, in the dissemination of EQA and governing policy.

\section{The ENQA}

The history of the ENQA goes back to the beginning of the 1990s when "national quality assurance agencies had started to arrange unofficial meetings in the early and mid-1990s in order to exchange information and, quite practically, to get to know each other" (Ala-Vähälä and Saarinen 2009, p. 90; see also Kauko 2012). This was a process in which Sweden was actively involved, and the country also became one of the early members in 2000. The European Commission had a general interest in supporting QA processes and took a particular interest in such activities in higher education, leading to a number of pilot projects (Enders and Westerheijden 2014; Kristensson 2010). After the finalisation of these projects, ministers for higher education in EU and EFTA/EEA countries, representatives for QA agencies, and associations for higher education met in Brussels for a conference where the ENQA network was launched (Thune 2010, p. 9). In 2011, it was transformed into the organisation European Association for Quality Assurance in Higher Education and kept its acronym ENQA. The stated mission of the organisation is to contribute to quality enhancement of European higher education, to develop QA processes, represent its members internationally, influence policymaking at the European level, promote cooperation among QA agencies, and "foster the European dimension of quality assurance of higher education" (ENQA statutes 2015, article 3). This is to be achieved by providing services and expertise, opportunities for networking, and coordinating external reviews of QA agencies. The ENQA also engages in the Bologna Process in projects, publication of reports and policy papers, and in cooperation with stakeholder organisations in higher education in Europe and worldwide (ENQA statutes 2015, article 4). European EQA policy travel through these 
activities, and are some of the means in operation to influence European countries. Activities like these are what Jacobsson (2010a, b) calls meditative processes. Another avenue for the ENQA to influence higher education through quality assurance policy and practice is the importance put on membership requirements.

\section{The ENQA's Membership Requirements and Sweden}

To become a member and have access to the ENQA's activities, member organisations must meet certain conditions (ENQA statutes 2015, article 5-8). There are two types of involvement: membership and affiliation:

Membership is open to European quality assurance bodies in the field of higher education that are conducting quality assurance activities as understood in the Standards and Guidelines for Quality Assurance in the European Higher Education Area (ESG) and act in compliance with the membership criteria. (ENQA statutes 2015, article 5)

The ESG is divided in three parts. The first part concerns quality standards and criteria for higher education institutions. The second part "basically required QA agencies to check how higher education institutions had implemented Part I, and in Part III required the QA agencies to be regularly reviewed themselves" (Enders and Westerheijden 2014, p. 173). Affiliation concerns QA bodies that cannot or do not wish to become members. Nonetheless, they still must agree to abide by the statutes of the ENQA, which in Jacobsson's (2010a, b) terminology would be considered governing by regulative activities.

ENQA regulations require member agencies to undergo an external review at least once every 5 years, which is an example of an inquisitive activity (Jacobsson 2010a, b). The SNAHE had been a member of the ENQA since 2000 and was also confirmed as a full member in 2005-2006 (SNAHE 2006). However, the EQA system established in 2011 was reviewed by an ENQA review panel in 2012 and assessed to be "fundamentally at odds with the ESG" (SNAHE 2012, p. 23). The main areas where the Swedish system deviated from ENQA principles were in not evaluating higher education institutions' internal QA systems and in not giving recommendations for improvement. Also, according to the review panel, the Swedish agency responsible for QA could not be considered independent (ENQA $2009,3.6)$ "due to the extent to which their procedures and methods, as well as overall aims and objectives have been dictated by government" (SNAHE 2012, p. 23). This news was highlighted in the University World News, which described the distress it caused in the higher education sector (Mycklebust 2012). Later the same year, the ENQA board decided that the Swedish agency was a "full member under review", and it was to be reviewed again in 2014 (ENQA 2012). However, in 2014, the criticised national EQA system was about to be phased out, and a new system was under development, and the application for full membership was to be postponed until the new national EQA system was in place. Since February 2014, the Swedish agency is not a member of the ENQA (ENQA 2014a). 
The national EQA system was critiqued, debated, and analysed by scholars across disciplines throughout the period of its existence of 2011-2014 (see, e.g. Adamson 2013; Ericsson 2014; Haikola 2013; Kettis and Lindberg-Sand 2013; Lundmark and Sjölund 2012; Sedigh 2013). It was challenged by the Association of Swedish Higher Education Institutions (ASHEI, SUHF Sveriges universitetsoch högskoleförbund $)^{2}$ and debated within the Swedish Association of University Teachers and Researchers (SAUTR, Sveriges Universitetslärares Förbund SULF) and by the Swedish National Union of Students (SNUS, Sveriges Förenade Studentkårer $S F S$ ). In these debates, the lost ENQA membership and suspension of the Swedish national agency (Swedish Higher Education Authority, SHEA) were used as arguments to reform the national EQA system. In an interview, one teacher union representative said the suspension was "embarrassing" (Dagens Arena 2014). The chairman of the national student union wrote that "Sweden cannot apply for new membership for another two years, which is a big blow to the international reputation of the Swedish education system" (Arroy 2014). The issue of ENQA membership was also brought up by the political opposition in parliament, and the Minister of Education from the Liberal Party framed his response this way:

\begin{abstract}
Mister President! Jabar Amin [MP from the Green Party] has asked me what I intend to do to guarantee that Sweden will have a quality assurance system that is good enough and may install confidence for Sweden in this respect. Ibrahim Baylan [MP from the Social Democratic Party, our clarification] has asked me what I have done to avoid a termination of the membership [in ENQA] and what measures I plan to take in order to reinstall confidence for the Swedish higher education system. (...) The SHEA is responsible for a development work where they, along with representatives for the higher education institutions, the students, and labour market undertake certain adjustments of the quality assessment system. With these adjustments, the SHEA should be able to fulfil the ENQA's requirements for full membership. (Parliament Minutes 2013/2014:81, p. 3)
\end{abstract}

In 2013, the SHEA was commissioned to develop a revised national EQA system, which was planned to be presented publicly in spring 2014 but was cancelled just prior to launch (SHEA Central staff). The ASHEI sent a proposal in April 2014 to the Ministry of Education in which they suggested a new EQA system for higher education where the responsibility for performing QA and evaluations would be transferred from the national agency to the higher education institutions themselves (ASHEI 2014). This was rapidly followed by an article in one of the national newspapers, signed by all vice chancellors and the chairman of the national student union. In the article, an overview of the proposed new system was presented (Svenska Dagbladet 2014). It was pointed out that the suggested system would be fully compatible with the ENQA membership requirements. An immediate response from the government was to assign a special investigator to develop and propose a

\footnotetext{
${ }^{2}$ This is an organisation in which the vice chancellors of all higher education institutions form a strong interest group that increasingly put pressure on the government and try to develop common advice for how to act in relation to the new policy landscape that opened up by recent reforms (ASHEI n.d.). Even though the ASHEI represents the name of the entire higher education sector, the organisation does not necessary represent teacher and researcher interests and opinions.
} 
new national EQA system (Government Office 2014). The instructions said that "principles for quality assurance at the European level shall be taken into account" (Government Office 2014, p. 1).

\section{European Policy Enters a Proposed National EQA System}

In April 2014, the government appointed the soon-to-be university chancellor and Director General of the SHEA as the special investigator. The instructions concerning European-level principles stated that the new system should include the higher education institutions' (HEI) own work on QA and that the system should be quality driven and give the HEIs recommendations to improve education (Government Office 2014, p. 1).

As will be shown in the chapter "Hayek and the Red Tape: The Politics of Evaluation and Quality Assurance Reform - From Shortcut Governing to Policy Rerouting", the preparation with the special investigator's proposal involved a large number of stakeholders (see also the chapter "Enacting a National Reform Interval in Times of Uncertainty: Evaluation Gluttony Among the Willing"). At this time, new ENQA standards and guidelines were proposed but not decided on, although a preliminary version from September 2014 had been presented (ENQA 2014b) and was taken into account. The special investigator presented her suggestion to the government in late 2014. Afterwards, in March 2015, the government crafted a memorandum through which their ideas concerning a new national EQA system was circulated to the HEIs and other stakeholder organisations for comments (Ministry of Education 2015). The memorandum was said to outline an overall framework, and the SHEA was then responsible for developing and implementing the details and design of this new system. In this work, the agency was to pay attention to the government's considerations as well as to national laws and ordinances. The agency was also to adhere to the international principles for QA that were developed within the framework of the Bologna Process (Ministry of Education 2015).

Throughout the memorandum, the importance of developing the system in accordance with European and international QA principles was put forward, and the Ministry clearly referred to the ESG and to the organisations involved in and responsible for them (Ministry of Education 2015, pp. 11-12). An overall emphasis was also put on an EQA system that should help improve higher education and not only control for results.

In the following political process, the European policy on EQA for higher education continued to be prominent in the Swedish context. The government collected comments from the HEIs and other stakeholders during 2015 and produced a government petition (2015/2016:76) to the parliament in December 2015 in which it once again was stressed that a new national EQA system for higher education should take into account "those principles that have been put forward within the frames of the Bologna process" (Government Petition 2015/2016:76, p. 7). This was also endorsed by many of the stakeholders in their comments on the government memo- 
randum (Ibid.). To provide background for the position taken, the government petition described the political aims with the ESG and the ENQA and what had happened to the Swedish agency's membership in that organisation (Ibid.).

The Parliament Standing Committee on Education handled the issue further, and in its discussions of the government petition, it also brought forward the European principles for QA (Parliament Standing Committee on Education 2016, pp. 17-18). The committee's proposal to the parliament also accounted for the Swedish agency's membership status in ENQA and described the process that led to the termination of ENQA membership (Parliament Standing Committee on Education 2016, p.14). In March 2016, the parliament finally decided on a new national EQA system in line with the framework set out by the government (Parliament Decision 2015/2016:155).

While they were waiting for a definitive parliamentary decision to launch a new national EQA system, the SHEA began developing and testing some of its planned components, some of which were already suggested in the 2015 Ministry memorandum (for instance, in the format of pilot evaluations of $\mathrm{PhD}$ programmes). This work continued in 2016 and 2017 when the SHEA performed pilots of the main parts of the new EQA system (SHEA 2016a, 2017, 2018). The new and existing system and its design and implementation process are explored in more detail in the chapters "Re-launching National Evaluation and Quality Assurance: Expectations and Preparations" and "Re-launching National Evaluation and Quality Assurance: Governing by Piloting". In the context of this chapter, however, we want to highlight that the SHEA repeatedly and consistently underlined the importance of the ESG in all its activities related to developing the design of and pilots of the new system. As an illustration, this was evident in the SHEA Guidelines for HEIs' selfevaluations and external assessor panels in the pilot evaluation of institutional reviews that should assess the HEIs' internal QA systems (SHEA 2016b). In those guidelines, particular standards and the ESG as a whole were referenced in detail. Occasionally, there were translations almost to the letter, as is the case concerning the ESG 1.2 and 1.3 (ESG 2015, pp. 11-12) and their equivalents, Aspects 3.1 and 3.2 in the SHEA Guidelines (SHEA 2016b, pp. 22-25).

As we have shown so far, the national political context matters (cf. Ozga and Jones 2006) when it comes to how receptive Sweden has been in relation to European EQA policy. When the Swedish agency's ENQA membership status was finally revoked in 2014, concerns were raised from many stakeholders pointing to the lack of international legitimacy of the Swedish EQA system. One way of coming to terms with these national concerns was to develop a new national system more in line with the ESG. Our data recurrently display how policymakers and stakeholders in the higher education sector were preoccupied with regaining international legitimacy through the adoption of the ESG and reinstated ENQA membership. This is evidenced by continual references to and arguments for the importance of adherence to European policies in matters that were voiced in the national political debate. This is what Sassen (2007) refers to as the important policy work necessary for national agreement on issues where oppositional views exist. Such work is also needed to facilitate policy translation work to fit a specific national context (Ozga 
and Jones 2006; Steiner-Khamsi 2004; Shattock 2014). We will get back to these issues in the chapter "Re-launching National Evaluation and Quality Assurance: Expectations and Preparations" where the design work of the 2016 system is further scrutinised.

We have also shown that the European EQA policy influenced Swedish national EQA policy, later resulting in the new national EQA system of 2016. Some of the explanations for this state of affairs were also given by what we call the policy brokers or elites (c.f. Lawn and Lingard 2002). Next, we turn to these policy brokers and their experiences of how and what policies travel with an emphasis on the routes or channels policy takes in entering and circulating in Sweden, what we here call dissemination. We use the concept of dissemination to denote an intentional process of negotiating and spreading policy to different (European) countries and to different actors within countries. We also conceive dissemination to be akin to circulation, meaning that some ideas are spread widely and become authoritative by such a process (Sahlin and Wedlin 2008). The idea of channels developed from empirical data where some organisational relations turned out to be rather prominent. This inspired us to view dissemination of EQA policies through these channels.

\section{EQA Policy Dissemination}

In the following section, we first describe the European and other organisations' links to Sweden before moving on to describe the internal Swedish dissemination channels. The types of dissemination activities and the primary content of those activities are also reported.

\section{European and Other Dissemination Channels}

Overall, the channels through which European EQA policies for higher education travel, are disseminated, and enter Sweden are generally bi- or multidirectional. But it is quite clear that the predicament with the questioned, and later revoked, ENQA membership made Swedish policy actors and brokers more receptive and sensitive to European and ENQA influences, giving the policy flow a more unidirectional character during this period.

The ten policy brokers we interviewed worked in the Ministry of Education, the SHEA, the ASHEI, teachers and student unions, and a lobby organisation. Many of these persons had experiences from different parts of the higher education sector, including political and/or administrative offices and/or high-level leadership positions in HEIs.

The policy brokers talked about a number of European, global, and Nordic organisations as particularly important for them and the organisations they represented in relation to EQA (see Fig. 1). Not surprisingly, informants at the 


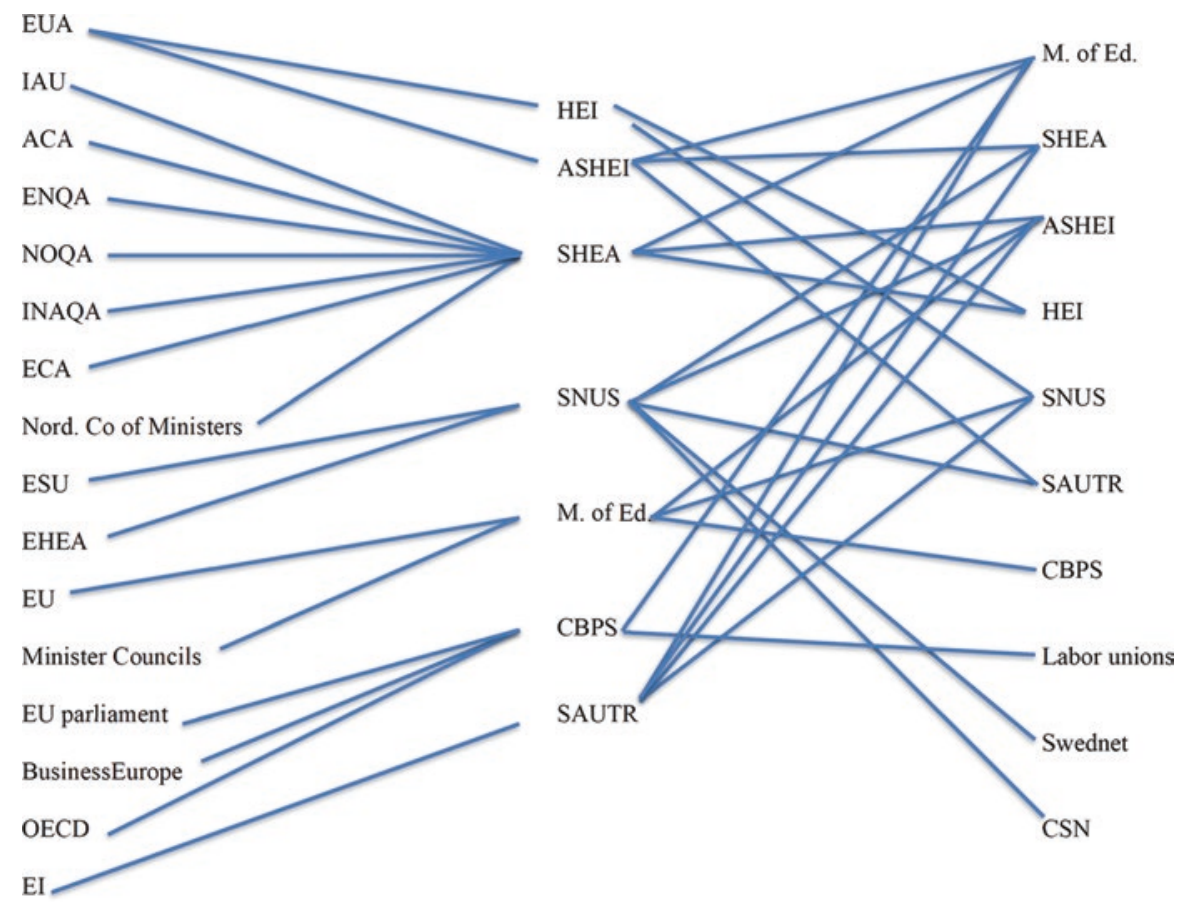

Fig. 1 From left to right: European/international to Swedish dissemination channels; internal Swedish dissemination channels

SHEA were involved with the highest number of international organisations, since the SHEA as a national agency is responsible for the supervision of higher education and is expected to engage in EQA policy and practice and promote such activities. Important organisations for these policy brokers were the ENQA (emphasising the ESG), the European Consortium for Accreditation in Higher Education (ECA), and the European Quality Assurance Forum (EQAF). The International Association of Universities (IAU) and the International Network for Quality Assurance Agencies in Higher Education (INQAAHE) were put forward. As non-European organisations, the Nordic Quality Assurance Network in Higher Education (NOQA) and the Nordic Council of Ministers were also stressed.

Another central policy actor when it comes to higher education policy and EQA is, of course, the government and its Ministry of Education. In our interviews, Ministry participants mentioned the European Commission and the Council of Ministers and the Nordic Council of Ministers as important venues for Sweden concerning policy information and discussions about EQA policy in higher education. Again, this is hardly surprising, as these channels are the formal ones one would expect European policies to take.

Ever since the so-called autonomy reform in Sweden was decided upon in 2010, leaving space for the HEIs to decide on internal organisation and positions (see 
the chapter "National Evaluation Systems"), the ASHEI has increasingly worked to establish a common policy platform for the Swedish HEIs and has strengthened its influence on national policy. This actor organises the vice chancellors of higher education and has a task force solely working with issues of EQA. The ASHEI participants claimed that their most important international contacts in this respect were with the European University Association (EUA), and, as the ASHEI in a way represents the HEIs, respondents indicated that the EUA is also an essential contact for the HEIs.

Another policy actor is the Centre for Business and Policy Studies (CBPS, Studieförbundet Näringsliv och Samhälle SNS), which organises private companies, research organisations, public enterprises, and national agencies. It engages in policy activities, research, lobbying, and policy advocacy concerning all areas of societal welfare. Our informant at this organisation said that the main policy contacts for them, in relation to EQA and higher education policy outside Sweden, are the European Parliament, BusinessEurope, ${ }^{3}$ and the Organisation for Economic Co-operation and Development (OECD).

Two policy brokers in our sample representing teachers, researchers, and students in higher education were from the SAUTR and the SNUS. The informant at the first organisation brought forward the Education International ${ }^{4}$ (EI) as an important link for them in relation to EQA. The second recognised the European Students' Union (ESU) as an organisation that they interact a lot with. The EHEA was also mentioned as a more general resource for their policy work.

\section{What Policy Is Important for Sweden?}

We also found it interesting to take a closer look at which issues, according to the policy brokers, some of the European actors disseminate in Sweden. Not surprisingly, the ENQA and its interest in QA models and systems were most often mentioned by the policy brokers. They indicated that the ENQA offers a possibility to review QA models in other countries and compare them to the Swedish model, thereby making it possible to assess the Swedish model and to monitor the changes in EQA policy. The policy brokers said that the ENQA paves the way for international agreements like the ESG and is important for mutual recognition of different kinds of higher education systems in European countries. This is significant for future student exchanges among European countries, they explained. Additionally, the ENQA provides opportunities to reconsider boundaries between politics and academics

\footnotetext{
3 "BusinessEurope is the leading advocate for growth and competitiveness at European level, standing up for companies across the continent and campaigning on the issues that most influence their performance" (BusinessEurope n.d.).

${ }^{4} \mathrm{EI}$ is a global umbrella organisation for labour union organisations for teachers and researchers in preschool up to higher education.
} 
and can help politicians understand that they have to work with the academic community and not against it, as one informant put it.

Another often mentioned association was the EUA, and the topic that was most interesting for Swedish policy was different aspects of autonomy for the HEIs in relation to central state power and authority. EUA conferences and study visits are argued to give insight opportunities to compare Swedish HEIs with other European HEIs. This comparison has, according to the policy brokers, shown that the autonomy for Swedish institutions is more restricted compared to other European countries. The HEIs in other countries are claimed to be more trusted than the Swedish ones, and in these countries, the HEIs also take a greater responsibility for their internal quality. One of the policy brokers said:

The great boundary line, I think, is between the systems that trust the universities and the ones that don't trust the universities. Sweden has had a system where they don't trust the universities; we have had that for many, many years in different shapes. I hope for a change towards a system that trusts the universities. If you make this distinction, the result will be two completely different models. (PB4)

Different European organisations also nourish conflicting interests in Sweden. The ESU is argued to be important in their resistance to the OECD's instrumental views of higher education - that education primarily should serve the labour market-according to the SNUS informant. Then again, the representative for the CBPS emphasised BusinessEurope in their mission of emphasising the importance of education and training in relation to the need for the labour market and public welfare.

Taken together, dissemination of EQA policy runs through channels with the help of a variety of activities that are designed to bring people and organisations together. In our interviews, such activities were described as conferences, workshops, annual membership meetings, formal meetings, study visits to other countries, hearings, and dialogues. Several of these are face-to-face activities and were talked about with enthusiasm by the informants. They resemble what Jacobsson (2010a, b) calls meditative activities and very much rely on social skills to be convincing enough to inspire travel and translation into different national and local contexts.

\section{Internal Swedish Dissemination Channels}

Within Sweden, the picture is more complex, indicating interesting connections between different organisations and actors that might aid further dissemination (see Fig. 1). Starting with the Ministry of Education, the informants there said that they "naturally" interact with the SHEA. Other connections of importance are the ASHEI, the SAUTR, the SNUS, and the CBPS. One informant also said that particular private companies may be of interest.

The SHEA informants equally "naturally" mentioned the Ministry of Education, the HEIs, the SAUTR, and the ASHEI as central to their work with evaluation and 
EQA policy, as these are regarded as the primary stakeholders. The ASHEI, in turn, had a mutual interest in the SHEA, the Ministry of Education, the HEIs, and the SNUS. The informant at the SAUTR stressed the relation to the SNUS, and of course to the HEIs, but also mentioned the Ministry of Education and the SHEA. Likewise, the SNUS informant talked about the link to the SAUTR but also mentioned other unions that organise HEI teachers, researchers, and other professionals with higher education degree requirements, like the Swedish Confederation of Professional Employees (Tjänstemännens centralorganisation, $T C O)$. This informant also said that $\mathrm{Swednet}^{5}$ is important for their policy work.

The informant from the CBPS said that as they are an organisation based on membership organisations, their important contacts are with their members and also with the Ministry of Education when it comes to EQA issues in education in a Swedish policy context.

When we conducted the interviews with this selection of policy brokers, it also became evident that they, as individuals, are themselves channels or "carriers" (Sahlin and Wedlin 2008, pp. 228-229) for EQA policy dissemination. As we showed in the chapter "National Evaluation Systems", the number of national evaluations and evaluators was very restricted in the 1970s, and the knowledge they generated did not feed into national or institutional politics and policy in any substantial way; it seems as not very much brokering or dissemination was taking place. This has changed, but the number of actors who are now involved in policy brokering and act as carriers of higher education EQA policy between Europe and Sweden is still rather small. They move between employment at HEIs, the national agencies, the Ministry of Education, and other influential organisations. This means that the governing power within Sweden is quite concentrated to these individuals: they are themselves both carriers and channels.

There are a large number of organisations, particularly European, that are involved in, or more specifically work with, EQA issues in higher education. Although the informants did not mention all possible organisations, it was nevertheless clear that comprehensive discussions and other types of policy work are broadly conducted in this respect. Dissemination of EQA policy seems to run through organisational links between similar actors and/or functions in the European and international contexts and the Swedish context. Politicians meet and disseminate policy to other politicians; national agency staff and quality experts meet and disseminate EQA policy to others in similar organisations, positions, etc. We interpret this to mean that the channels between European and global policy spaces and Sweden appear to be quite insulated from each other. But when we add the internal Swedish dissemination channels to the European/global channels, there is some evidence that EQA policy nevertheless is disseminated rather widely, all the way into Swedish higher education institutions, and the SHEA plays a significant role in this respect. (See Fig. 1)

\footnotetext{
${ }^{5}$ Swednet is a formal Swedish network for pedagogic development in higher education (Swednet n.d.).
} 


\section{Discussion}

Our findings show that the ENQA membership, or rather the revoked membership, was presented as an essential issue in the national EQA policy processes. After having been one of the early members, the Swedish national agency was denied membership in 2014. This status was a result of the 2011-2014 EQA system and came to be portrayed as a national and international embarrassment. We think this is a clear example of how the open method for coordination works. The ENQA membership requirements are tied to the adherence of the ESG for aspiring members, and the ESG are examples of: "jointly established measuring instruments (statistics, indicators, guidelines); benchmarking, i.e. comparison of EU countries' performance and the exchange of best practices (monitored by the Commission)" (EUR-Lex n.d.). We have also shown that becoming a full member again was framed as an important political goal and used as a way to re-establish the lack of national legitimacy and criticism of the 2011-2014 system. The government and the national agency SHEA did this by stressing the European EQA policy and the ESG. As Sassen (2007) emphasised, this points to the importance of the policy work needed by the nation-state to make international/global policy attractive to the national context. Not only have several nation-states come to agreements over joint standards, but individual nation-states have had to reconcile internal conflicts and interests to form a receptive national context for external policy to enter and influence the national policy.

Other means for European EQA policy to travel and influence national policies are also evident. In the case of EQA policy and practice, our study shows that meditative activities (Jacobsson 2010a, b) like taking part in European/international networks, conferences, meetings, etc. are important in governing and policy work. In relation to the ENQA membership situation, regulative and inquisitive activities also become indirectly important. This is because becoming a member means adhering to certain rules and regulations, ENQA statutes, and the ESG, which means engaging or performing activities that are in line with these requirements. Complying with the ESG also means opening up for reviews and assessments by external bodies. Taken together, these activities most likely are strong governing powers for those who aspire to become and remain members, as member agency reviews are conducted every 5 years. For Sweden, this means that when the SHEA applies for a new membership, such activities will take place, and the 2016 national EQA system was designed in line with the ENQA membership requirements, which we come back to in the chapter "Re-launching National Evaluation and Quality Assurance: Expectations and Preparations". Knowledge carried by the policy brokers about how to design the Swedish EQA system to be in line with the ENQA requirements have been a condition for European policy to enter Sweden and hence influence national governing of higher education.

This EQA policy travels well through the channels we have described and through the governing activities (Jacobsson 2010a, b) we discussed above. In these encounters (conferences, networks, etc.), knowledge about EQA is exchanged, 
learned, and brokered. Freeman and Sturdy (2014) proposed that three forms of knowledge are activated in policy processes: embodied, inscribed, and enacted. We find that all three forms are probably present in the dissemination processes and channels. The policy brokers bring experiences of EQA work with them to meetings and conferences, which is akin to embodied knowledge that travels with "carriers" (Sahlin and Wedlin 2008, pp. 228-229). Inscribed knowledge is present in the ESG, in formal presentations, reports, and papers circulated and disseminated, and this kind of knowledge is easy to move and reproduce. Enacted knowledge is present in the actions taking place, for example, when presentations and reports are discussed and translated to fit into new contexts.

The exchange of EQA knowledge is often done by comparing national models and systems, both entire education systems and specific EQA systems. We find that comparisons are important as a condition for European EQA policy influence in higher education in that they are necessary for making adjustments in line with the ESG. By exchanging knowledge and experiences of how different national (regional) EQA systems are designed so as to be in line with the ESG, national policy brokers may bring this knowledge "home" and influence the national policy context. Comparisons are also used as a means to know what in the dissemination of EQA (and other) policies is of interest, useful, and possible to get acceptance for in a national context. In the Swedish case, it is clear that a main policy driver for the development of the 2016 system was the ESG, meaning that these standards and guidelines became influential in the attempts to govern higher education institutions, a finding we will elaborate on in the chapters "Enacting a National Reform Interval in Times of Uncertainty: Evaluation Gluttony Among the Willing" and "Re-launching National Evaluation and Quality Assurance: Governing by Piloting".

Since 50 quality assurance agencies are full members of the ENQA and comply by its statutes, the EGS arguably hold a dominant position in the field of EQA policy in European higher education. The ESG acquire increased policy and governing power in this circulation of EQA ideas, as described by Sahiln and Wedlin (2008). The ESG are discussed, read, and worked with in relation to EQA systems designs. Through this kind of circulation of ideas carried by interested and influential policy elites, the ideas become attractive or fashionable. With reference to Czarniawska and Sévon (2005), Sahiln and Wedlin write about fashion:

Fashion guides imitation and the attention of actors to specific ideas, models, and practices, and fashion identifies but also creates what is appropriate and desirable at a given time and place. This leads organizations to adopt, but also to translate, these ideas, thus changing both what is translated and those who translate. (Sahlin and Wedlin 2008, p. 222)

The number of actors and people involved in EQA policymaking and dissemination is noteworthy. We only portray one comparatively small country. Considering the European and Bologna context of higher education in total makes us aware of the large number of people who must be involved in these policy activities and the 
dissemination of European EQA policy to the different European Union countries as well as inside these countries. Lingard and Rawolle (2011) discussed this growth and dispersion of politics and policy in terms of a rescaling process that we find is a useful characteristic for EQA policy as well:

It is the growing importance of this hybrid mix of global and national factors that we refer to as a rescaling of educational politics and policies, into which national policies and their effects are increasingly drawn and reconstituted in a global field of comparison. (Lingard and Rawolle 2011, p. 492)

They also argue that:

Another productive way of conceptualising this rescaling is in respect of the relocation of political authority-'outward toward supranational entities and inward toward subnational groups.' (Rosneau and Czempiel 1992, pp. 2-3, in Lingard and Rawolle, 2011, p. 490)

In this chapter, we do not exactly point to where the political authority is located or if it is relocated, but clearly political authority concerning EQA in higher education now has a firm base within the ENQA at the European level. The location or relocation within Sweden has yet to be explored fully, but a tendency is re-centralisation, despite the intentions of the previously mentioned autonomy reform. We have noted that the ASHEI has become an increasingly powerful organisation that tries to bring about common policies for the HEIs in Sweden in several areas (e.g. resources, employment, organisation, internal governance; ASHEI n.d.) in the wake of the "freedoms" of the autonomy reform. This points to efforts to centralise within the HEI sector itself, where individual HEIs adjust to the agenda set by the ASHEI. An additional example of centre-local relocation may be the government's recent decision to commission the SHEA to evaluate and quality assure all activities at the HEIs, including research (Government Office 2017). This is a new development that shifts authority and governing of research from the HEIs to the national authority (the State).

\section{Finally}

In pursuing the tendency to relocate authority within the higher education sector, we find the vice chancellors to be an important group, as they occupy a central function at higher education institutions concerning EQA policy and practice. In their capacity of being the executive leaders of the higher education institutions, they may be rather influential in EQA matters within their respective institutions. In the next chapter, their views of the mission of the university, of quality in higher education, and of national EQA are described and analysed. 


\section{References}

Adamson, L. (2013). Kvalitetsutvärdering av högre utbildning - en kritisk granskning av det svenska systemet framtagen på uppdrag av SNS Utbildningskommissionen [Quality evaluation of higher education - A critical review of the Swedish system as a commission for the SNS's Educational Committee]. Stockholm: SNS.

Ala-Vähälä, T., \& Saarinen, T. (2009). Building European-level quality assurance structures: Views from within ENQA. Quality in Higher Education, 15(2), 89-103.

Arroy, E. (2014, March 7). SFS: Utvärderingen av våra utbildningar fungerar inte (Evaluation of our higher education does not work). Dagens Arena. Retrieved March 10, 2014, http://www. dagensarena.se/opnion/sfs-utvarderingen-av-vara-utbildningar-fungerar-inte/

ASHEI (2014). Hemställan om åtgärder avseende kvalitetssystem för högre utbildning. 201404-11, Dnr 14/029. [Request about actions concerning quality systems for higher education]. Retrieved August 12, 2015, http://www.ASHEI.se/publicerat/skrivelser

ASHEI. (n.d.). Sveriges universitets- och högskoleförbund. http://www.ASHEI.se. Accessed 5 Aug 2017.

BusinessEurope. (n.d.). Our mission. https://www.businesseurope.eu/mission-and-priorities. Accessed 6 July 2017.

Czarniawska, B., \& Sévon, G. (Eds.). (2005). Global ideas: How ideas, objects and practices travel in the global economy. Malmö: Liber and Copenhagen Business School Press.

Dagens Arena. (2014, March 3). Sverige utesluts ur utbildningsnätverk (Sweden is excluded from education network). http://www.dagensarena.se/innehall/sverige-utesluts-ur-utbildningsnatverk/. Downloaded 4 March 2014.

EHEA. (n.d.-a). www.ehea.info. Accessed 19 Nov 2014.

EHEA. (n.d.-b). www.ehea.info/article-details.aspx?/Articleid=24. Accessed 19 Nov 2014.

Enders, J., \& Westerheijden, D. F. (2014). Quality assurance in the European policy arena. Policy and Society, 33(3), 167-176.

ENQA. (2009). Standards and guidelines for quality Assurance in the European Higher Education Area (3rd ed.). Helsinki: ENQA.

ENQA. (2010). ENQA: 10 years (2000-2010). A decade of European cooperation in quality assurance in higher education. Helsinki: ENQA.

ENQA. (2012). Letter from Achim Hopbach, President of ENQA, to Dr. Lars Haikola, University Chancellor and Head of the Swedish National Agency for Higher Education, 17 September, 2012.

ENQA. (2014a). Letter from Padraig Walsh, President of ENQA, to Lars Haikola, University Chancellor of the Swedish Higher Education Authority, 25 February, 2014.

ENQA. (2014b). Standards and guidelines for quality Assurance in the European Higher Education Area (ESG) (Endorsed by the Bologna Follow-Up Group in September 2014). Helsinki: ENQA.

ENQA. (2015). Statutes of the European Association for Quality Assurance in Higher Education. Retrieved April 2018, http://www.enqa.eu/wp-content/uploads/2016/05/ENQA-Statutes2015-EN.pdf

Ericsson, M. (2014). Analys av Universitetskanslersämbetets utvärderingar av utbildningskvalitet år 2011-2014 [Analysis of the SHEA's evaluations of education quality years 2011-2014]. Stockholm: KTH. e-mail: merics@kth.se.

EUR-Lex. (n.d.). Open method of coordination. http://eur-lex.europa.eu/summary/glossary/open_ method_coordination.html. Accessed 27 Dec 2016.

Franke, S., \& Nitzler, R. (2008). Att kvalitetssäkra högre utbildning - en utvecklande resa från Umeå till Bologna. [To assure quality in higher education. A developmental journey from Umeå to Bologna]. Lund: Studentlitteratur.

Freeman, R., \& Sturdy, S. (2014). Introduction. In R. Freeman \& S. Sturdy (Eds.), Knowledge in policy. Embodied, inscribed, enacted (pp. 1-17). Bristol: Policy Press. 
Government Office. (2014). Press release 8 April 2014. Harriet Wallberg Henriksson utreder systemet för kvalitetssäkring av högre utbildning [Harriet Wallberg Henriksson investigates the national quality assurance system in higher education]. Retrieved April 10, 2014, http:www. regeringen.se/sb/d/18276/a/238291

Government Office. (2017). Press release, 7 July 2017. Kvalitetssäkring av forskningsmiljarder förstärks [Strengthend quality assurance of research billions]. Retrieved July 7, 2017 , http://www.regeringen.se/pressmeddelanden/2017/07/kvalitetssakringen-av-forskningsmiljarderforstarks/

Government Petition 2015/2016:76. Kvalitetssäkring av högre utbildning [Quality assurance of higher education]. Retrieved March 22, 2016, http://www.regeringen.se/rattsdokument/ skrivelse/2015/12/skr.-20151676/

Grek, S., \& Lawn, M. (2012). Europeanizing education. Governing a new policy space. Oxford: Symposium Books.

Haikola, L. (2013). Reflektioner kring det nuvarande utvärderingssystemet. Erfarenheter 2011-september 2013 [Reflections on the present evaluation system. Experiences 2011-September 2013]. Stockholm: SHEA.

Jacobsson, B. (2010a). Making sense of Europeanization. Jerusalem papers in regulation \& governance (Working Paper No. 11, June 2010). Jerusalem: The Hebrew University, Jerusalem Forum on Regulation \& Governance.

Jacobsson, B. (Ed.). (2010b). The European Union and the Baltic States. Changing forms of governance. London: Routledge.

Kauko, J. (2012). The power of normative coordination in the Bologna process: How universities learned to stop worrying and to love quality assurance. Journal of the European Higher Education Area, 2012(4), 23-40.

Kettis, A. \& Lindberg-Sand, A. (2013). Det svenska kvalitetssystemets kval - en dialog från olika utgångspunkter [The anguish of the Swedish quality system. A dialogue from different viewpoints.] Högre utbildning 3(2), 139-149.

Kristensson, D. (2010). From the First Pilot Projects to the Founding of ENQA (1994-2000). In ENQA: 10 years (2000-2010). A decade of European co-operation in quality assurance in higher education (pp. 5-7). Helsinki: ENQA.

Lawn, M. (2006). Soft governance and the learning spaces of Europe. Comparative European Politics, 2006(4), 272-288.

Lawn, M., \& Lingard, B. (2002). Constructing a European policy space in educational governance: The role of transnational policy actors. European Educational Research Journal, 1(2), 290-307.

Lindgren, J., \& Rönnberg, L. (2015). The emotional politics of policy processes. Governing in and by quality evaluation reforms in Swedish Higher Education. Paper presented at the European Conference for Educational Research in Budapest, 8-11 September, 2015.

Lingard, B., \& Rawolle, S. (2011). New scalar politics: Implications for education policy. Comparative Education, 47(4), 489-502.

Lundmark, A., \& Sjölund, M. (2012). Håller utvärderingsmetoden tillräcklig kvalitet? En uppföljning vid Uppsala universitet av Högskoleverkets system för kvalitetsutvärdering 20112014. Första omgången [Is the quality of the evaluation model good enough? A follow-up at Uppsala University of the SNAHE's system for quality assurance 2011-2014. First cycle]. Uppsala: Uppsala universitet, Enheten för kvalitet och utvärdering.

Maassen, P., \& Stensaker, B. (2011). The knowledge triangle, European higher education policy logics and policy implications. Higher Education, 61(6), 757-769.

Ministry of Education. (2015). Promemoria. U2015/1626/UH. Kvalitetssäkring av högre utbildning [Quality assurance of higher education]. Retrieved April 18, 2018, http://www.regeringen. se/rapporter/2015/03/u20151626uh/

Mycklebust, J.P. (2012, May 6). Quality assurance regime fails to meet European standards. UniversityWorldNews. http://www.universityworldnews.com/article.php?st ory $=20120503164105608$. Accessed 8 July 2015. 
Ozga, J., \& Jones, R. (2006). Travelling and embedded policy: The case of knowledge transfer. Journal of Education Policy, 21(1), 1-17.

Ozga, J., Dahler-Larsen, P., Simola, H., \& Segerholm, C. (Eds.). (2010). Fabricating quality in education. Data and governance in Europe. London: Routledge.

Parliament Decision 2015/2016:155. Riksdagsskrivelse [Parliament decision]. Retrieved 18 April, 2018, https://www.riksdagen.se/sv/dokument-lagar/dokument/riksdagsskrivelse/ riksdagsskrivelse-201516155_H30K155

Parliament Minutes 2013/2014:81. Svar på interpellationerna 2013/14:314 och 319 om kvalitetsutvärderingssystemet för den högre utbildningen [Answer on parliamentary questions 2013/14:314 and 319 concerning the quality assurance system in higher education]. Retrieved March, 2014, http://www.riksdagen.se/sv/Dokument-Lagar/Kammaren/Protokoll/ Riksdagens-snabbprotokoll-2013_H10981/

Parliament Standing Committee on Education 2015/2016:UbU9. Kvalitetssäkring av högre utbildning [Quality assurance of higher education]. Retrieved March 22, 2016, https://data.riksdagen.se/fil/BFE0EB56-062B-4AA8-BBE3-794EE45BB9CF

Rosneau, J. N., \& Czempiel, E.-O. (Eds.). (1992). Governance without government: Order and change in world politics. Cambridge: Cambridge University Press.

Sahlin, K., \& Wedlin, L. (2008). Circulating ideas: Imitation, translation and editing. In R. Greenwood, C. Oliver, K. Sahlin, \& R. Suddaby (Eds.), The SAGE handbook of organizational institutionalism (pp. 218-242). Thousand Oaks: SAGE Publications.

Sassen, S. (2007). A sociology of globalization. New York: W. W. Norton \& Company, Inc.

Sedigh, M. (2013). External quality assurance and its impact on internal quality management. A review of the Higher Education Authority's evaluation system for quality assessments 20112014. Stockholm: Swedish Higher Education Authority, and the author (status unclear).

Segerholm, C., \& Hult, A. (2015). Manoeuvring in the European quality landscape: The significance of ENQA policy in governing Swedish higher education. Paper presented at the European Conference for Educational Research in Budapest, 8-11 September, 2015. Umeå: Umeå University, Department of Education.

Segerholm, C., \& Hult, A. (2017). Channels for European quality assurance policy in higher education - The Swedish example. Paper presented at the European Conference for Educational Research in Copenhagen, 22-25 August 2017. Umeå: Umeå University, Department of Education.

Shattock, M. (Ed.). (2014). International Trends in University Governance. Autonomy, selfgovernment and the distribution of authority. Oxon: Routledge.

SHEA. (2014). Personal communication with SHEA Central staff, May 2014.

SHEA. (2016a). Annual report for 2015. Stockholm: SHEA.

SHEA. (2016b). Guidelines for reviewing quality assurance procedures of higher education institutions. Pilot study. Stockholm: SHEA.

SHEA. (2017). Аnnual report for 2016. Stockholm: SHEA.

SHEA. (2018). Annual report for 2017. Stockholm: SHEA.

SNAHE. (2006). Evaluation of the Swedish National Agency for Higher Education. 31 January, 2006. Retrieved July 9, 2015, http://www.enqa.eu/wp-content/uploads/2007/05/Externalreview-report-of-the-Swedish-National-Agency-for-Higher-Education-HsV-May-2007.pdf

SNAHE. (2012). Swedish National Agency for Higher Education: Review of ENQA Membership. April 2012. HSV_review-ENQA-Criteria-Report-April2012 (1).pdf

Standards and Guidelines for Quality Assurance in the European Higher Education Area (ESG). (2015). Brussels, Belgium.

Steiner-Khamsi, G. (2004). The global politics of educational borrowing and lending. New York: Teachers College, Columbia University. 
Svenska Dagbladet. (2014). SvD Opinion. Brännpunkt. Kvalitetskontroll [SvD Opinion. Focal point. Quality control]. April 13, 2015. Retrieved April 14, 2015, http://www.svd.se/ universiteten-vi-kan-skota-granskningen

Swednet. (n.d.). http://www.swednetwork.se/hem/. Accessed 22 July 2018.

Thune, C. (2010). ENQA 2000-2005: From the launch of a professional network to the success in Bologna of a new association. In ENQA: 10 years (2000-2010). A decade of European cooperation in quality assurance in higher education (pp. 9-15). Helsinki: European Association for Quality Assurance.

Open Access This chapter is licensed under the terms of the Creative Commons Attribution 4.0 International License (http://creativecommons.org/licenses/by/4.0/), which permits use, sharing, adaptation, distribution and reproduction in any medium or format, as long as you give appropriate credit to the original author(s) and the source, provide a link to the Creative Commons license and indicate if changes were made.

The images or other third party material in this chapter are included in the chapter's Creative Commons license, unless indicated otherwise in a credit line to the material. If material is not included in the chapter's Creative Commons license and your intended use is not permitted by statutory regulation or exceeds the permitted use, you will need to obtain permission directly from the copyright holder.

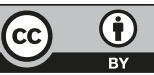

